\title{
UK urged to open up science advisory panels
}

Loughborough, UK. Pressure is building on the British government to increase the public's acceptance of science-related activities - for example, those relating to the applications of biotechnology and genetic engineering - by opening up its science advisory bodies to greater public scrutiny.

The pressure has highlighted differing, and occasionally conflicting, goals between those currently promoting the increased 'public understanding of science'.

Last week, David Hunt, in his first major speech as the new minister for science, told the annual meeting of the British Association for the Advancement of Science (BA) at the University of Loughborough that the government had decided to provide substantial extra support for various activities aimed at achieving this goal (see page 187).

Justifying these moves, Hunt said it was essential to stimulate a "proper dialogue" between government, industry and the scientific community - and between specialists and citizens. "We need to generate an excitement about science and the scientific world for future generations," he said.

But Hunt reacted coolly to a suggestion by the Financial Times newspaper that what was also needed was increased openness of government advisory committees (the US National Institutes of Healths' Recombinant DNA Advisory Committee, whose meetings are generally held in public, was quoted as an example to emulate).

The newspaper's proposals have some strong supporters in private industry. Con- cern is growing among biotechnology companies, for example, that the traditional secrecy which still surrounds much of the government's advisory machinery may itself be helping to generate a distrust towards their activities.

"If the legal process for getting clearance was more open, we believe that a lot of the current opposition would go away," says Louis da Gama, executive director of the BioIndustry Association. He points, for example, to the recent controversy surrounding the experimental release of a modified caterpillar virus carrying a scorpion toxin gene in a field in Oxfordshire (see Nature 369, 348; 1994).

A similar message seems likely to emerge from a 'consensus' exercise currently being carried out by the Science Museum on behalf of the Biotechnology and Biological Sciences Research Council, in which a lay panel has been set up to discuss in detail potential public concerns about plant biotechnology (see Nature 369, 435; 1994).

The conclusions of the panel, which has already met for a weekend of informal discussions, will not be finalized until a twoday public conference at the beginning of November. But according to John Durant, assistant director of the Science Museum, a key factor already emerging is the need to ensure the integrity and credibility of the regulatory process.

So far, however, the government appears to be relatively unmoved by demands that this would be enhanced by greater open-

\section{Demand grows for 'positive' gene therapy}

Upbeat media coverage of the first UK gene therapy trials for cystic fibrosis may have contributed to an almost threefold increase over the past year in public support for the use of genetic techniques to enhance desirable traits in children - a trend which is already generating some concern among British researchers.

A recent Gallup poll, commissioned by the psychology and genetics research group at Guy's Hospital in London and funded by The Wellcome Trust, showed that three times more people would now consider changing the appearance and behaviour of their children through the implantation or alteration of selected genes than admitted so a year ago in a similar poll conducted for The Daily Telegraph.

The overall figures remain relatively small. But this shift is already raising questions over how far the views of the general public should be taken into account in deciding policy guidelines on the application of gene therapy. "Do you want to incorporate public opinion where the vast majority might be eugenic?" Theresa Marteau, director of the group at Guy's Hospital, asked last week's meeting of the British Association for the Advancement of Science.

The numbers of positive responses to questions about such uses of gene therapy were still small, with no more than 20 per cent in any one case saying that they would use the technology if it were possible. But it is the rapid rise in acceptability over the past year that is potentially more significant.

For example, the percentage of respondents saying that they would use genetic methods to affect aggression rose from 5 per cent in 1993 to 18 per cent in 1994 . The corresponding increase for alcoholism was from 5 to 18 per cent, for homosexuality from 4 to 10 per cent, and for 'good looks' from 2 to 5 per cent.

Marteau suggested that the large amount of coverage about the gene therapy trials for cystic fibrosis may explain why the public has become "more positive" about the uses of gene therapy, even though they remain cautious.

Maggie Verral

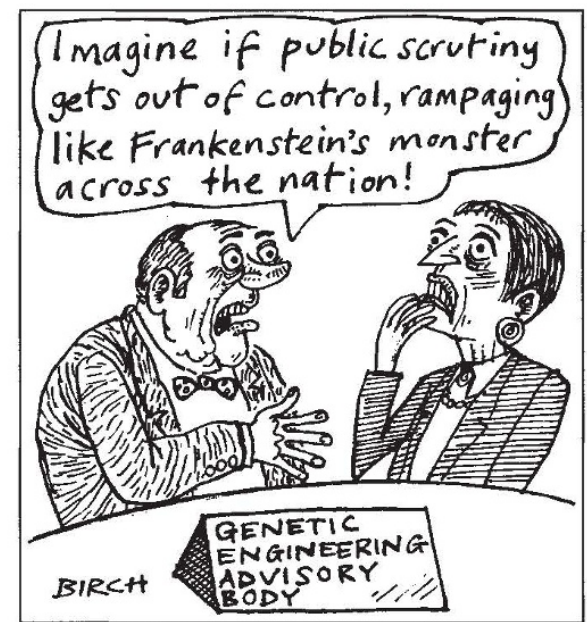

ness. Asked at a press conference for his reactions to the Financial Times' editorial, Hunt said that he wanted to see the whole process as open as possible — but that "on particular topics there is a need to call together experts in a private way".

The debate seems destined to intensify as government-funded efforts to increase the public understanding of science come under increasing scrutiny, inevitably including the motivations of those involved.

Jill Nelson, for example, head of science promotion at the Royal Society, told a separate meeting that scientific learned societies and professional bodies must think carefully about the relationship between their desire to promote science as a public duty, and that to push their corporate identity.

A survey of members of STEMPRA the recently formed Science, Technology, Engineering, Medicine Public Relations Association - showed that most professional societies combine their public understanding of science activities with their corporate press and public relations, with the same individuals often taking on both responsibilities because of limited resources. "When the society confuses the two objectives, it confuses the messenger and the message," said Nelson.

There was also a warning of the hazards facing social scientists attempting to increase their understanding of the way that scientists operate in a sharp exchange between Lewis Wolpert, the chairman of the Committee on the Public Understanding of Science, and Harry Collins, director of the Science Studies Centre at the University of Bath.

Having strongly criticized sociologists for the relativism of their theorizing, Wolpert at one point suggested that their main motivation was "envy" of their natural science colleagues, and that they suffered from a "massive inferiority complex". In return, Collins claimed that Wolpert was "engaging in a pantomime".

David Dickson and Maggie Verrall 